
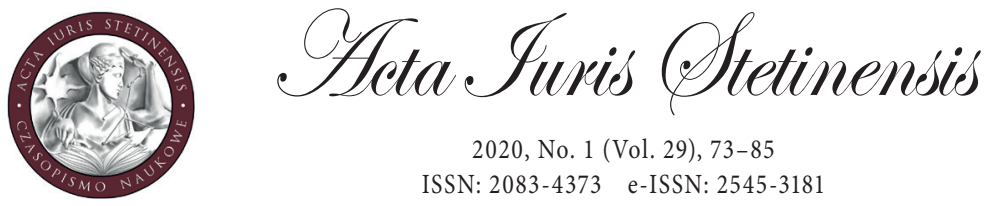

2020, No. 1 (Vol. 29), 73-85

ISSN: 2083-4373 e-ISSN: 2545-3181

DOI: $10.18276 /$ ais.2020.29-06

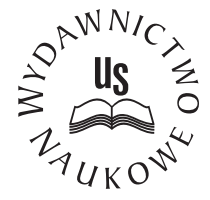

Damian Kuchta

MA

University of Lodz, Poland

Faculty of Law and Administration

e-mail:damian.kuchta@adwokatura.pl

ORCID ID: 0000-0002-8112-2928

\title{
The influence of the Act of 22 March 2018 on bailiffs on amendments to the Code of Civil Procedure regarding execution from remuneration for work
}

\begin{abstract}
The aim of this paper is to present the general issue of execution from remuneration for work and, in particular, the impact that the Act of 22 March 2018 on bailiffs had on changes in the Code of Civil Procedure. The paper uses the methods of critical analysis of sources and systematic review. So far, there has been no doubt that individuals employed under civil-law contracts are in a much worse situation than those employed under employment contracts. For this reason, the legislature wanted to protect them from execution, hence the introduction of a means to make their situation equal in Article $833 \$ 2^{1}$ of the Code of Civil Procedure. Despite the good intentions of the legislature, this provision still raises doubts over the wording: 'ensuring livelihood'. For this reason, the application of new provisions that limit the execution of recurring benefits aimed at ensuring subsistence - other than remuneration for work - requires appropriate action.
\end{abstract}

Keywords: execution, remuneration, labour, civil procedure code, bailiff 


\section{Introduction}

A frequently used method of executing a judgement is to withhold remuneration for work that has been done. This method ensures the effective satisfaction of the creditor, as remuneration for work is paid to debtors regularly. Execution from a claim for remuneration for work has, however, been abstracted by the legislature and designated as an independent method of execution. The provisions on execution from remuneration for work contained in the Code of Civil Procedure thus apply accordingly to other methods of execution, and can therefore be considered exemplary. Pursuant to Article 893 of the Code of Civil Procedure, Articles 885, 887, and 888 apply to the effects of an attachment of a bank account. The same applies to Article 899 of the Code of Civil Procedure, because according to it, when seizing a receivable secured by a surety, pledge, or registered pledge, a judicial officer, at the request of the creditor, also notifies the guarantor or the owner of the asset encumbered by the pledge that the benefit of the secured receivable cannot be paid to the debtor. Article $882 \$ 1.2$ of the Code of Civil Procedure - which enacts the obligation to notify the judicial officer of any changes in the state of the debt applies to this execution. Article $900 \$ 2$ of the Code of Civil Procedure also refers to the appropriate application of Article $883 \$ 2$ in the case of execution from sums payable periodically, including future payments. In turn, Article 902 provides that the provisions on execution from remuneration for work under Articles 885, 887, and 888 apply correspondingly to the consequences of attachment of a receivable debt. Article 886 applies mutatis mutandis to the consequences of failure to comply with a judicial officer's summons and obligations resulting from the seizure.

The title of Part Three, Title II, Chapter II of the Code of Civil Procedure 'remuneration for work' - and the provisions of that Chapter indicate that it refers to a specific type of debt. In the Code of Civil Procedure of 1930, execution of remuneration for work was not provided for as a separate method of execution at all. Execution proceedings were then carried out in accordance with the provisions on executing monetary claims and other property rights. The remuneration for work was therefore regulated on a par with the debtor's other claims. It was only in the Civil Procedure Code of 1964 that remuneration for work was described as an independent method of execution.

\section{Remuneration for commissioned work}

The provision in the second sentence of Article $881 \$ 2$ of the Code of Civil Procedure, which lists the exemplary components of pay for work, indicates pay for work to be performed. The linguistic interpretation and the phrase 'remuneration for 
commissioned work' allow us to assume that the Code of Civil Procedure in this part of the provision refers to civil-law relationships, and above all to the notion of commission. However, applying the interpretation by analogy, the 'commissioned work' should also refer to other civil-law contracts, e.g. contracts for specific work. Andrzej Marciniak, following the views of Michał Seweryński, assumes that recurring payments which - although they go beyond remuneration understood in this way, and are subject to execution from remuneration for work (e.g. remuneration for commissioned work) under the Code of Civil Procedure Article $881 \S 2$ - in light of the provisions restricting execution, are another type of recurring payments whose purpose is to ensure maintenance (payments referred to in Code of Civil Procedure Article $833 \$ 2$ ).

It should be pointed out that, until the end of 2018, the situation of employees regarding deductions had been better than that of contractors, although some protection against deductions had also been available to contractors. In Poland, more than 1.5 million people are employed under contracts of mandate. Indeed, for a large part of them the remuneration they receive under contracts of mandate is their only source of income. On 1 January 2019, protection against deductions of remuneration received by persons employed under civil-law contracts came into effect. Therefore, in accordance with the applicable regulations, the enforcement of the remuneration is limited both in the case of individuals employed under employment contracts and those performing work on the basis of civil-law contracts. Currently, contractors benefit from the protection of remuneration against excessive deductions on similar terms as employees. It should be noted, however, that the scope of this protection is not the same as in the case of employees, because the remuneration of contractors and other natural persons who are debtors is subject to protection as long as these are periodic payments that provide them with a livelihood or are their only source of income. Moreover, it should be pointed out that Article $833 \S 1$ of the Code of Civil Procedure does not regulate on its own the issue of excluding remuneration for work from enforcement, but refers in this respect to the Labour Code. Therefore, reference to the concept of remuneration for work as accepted under labour law is justified.

In labour law, the notion of 'remuneration for work' is understood as a financial and claim-like payment originating from the employment relationship, paid by an employer to an employee in return for work performed by him/her according to its type, quantity, and quality. ${ }^{1}$ However, in the provisions of the Code of Civil Procedure, the notion of 'remuneration for work' is defined separately in order

1 Szubert, W., Zarys prawa pracy, Warszawa 1976, p. 236; Seweryński, M., Wynagrodzenie za pracę. Pojęcie, regulacja i ustalanie, Warszawa 1981, p. 100. 
to determine the subject matter of enforcement from this remuneration. Pursuant to Article $881 \$ 2$, the subject of enforcement of remuneration for work is, in particular, periodic remuneration for work, remuneration for commissioned work, awards and bonuses to which the debtor (employee) is entitled for the period of employment, profit relating to the employment relationship, participation in the company fund, and any other funds relating to the employment relationship. The content of this provision engenders two general remarks.

First of all, it should be noted that the components of employee income listed therein are exemplary, as explicitly indicated by the phrase 'in particular'. Furthermore, the provision refers to the concept of remuneration for work not only as income from work performed in the context of the employment relationship, but also to income which an employee receives from his/her employer in connection with the employment relationship.

Therefore, it may be argued that the object of enforcement of remuneration within the meaning of Article $881 \S 2$ is any income that an employee receives from his/her employer in connection with their employment relationship. This applies both to remuneration for work within the meaning of the labour law ${ }^{2}$ (Articles 78-98 of the Labour Code) and other benefits owed to the debtor by the employer, in connection with both the employment relationship (e.g. awards) and other legal relationships (e.g. remuneration for work commissioned on the basis of a contract of mandate or contract for work). ${ }^{3}$

\section{Amendments to the Act of 22 March 2018 on bailiffs ${ }^{4}$}

On 1 January 2019, the amended Act of 29 August 1997 on bailiffs and judicial execution came into effect. In the current legal status there are two separate acts: the Act of 22 March 2018 on bailiffs and the Act of 28 February 2018 on bailiff costs. ${ }^{5}$ The new laws introduced many changes to the system, as well as to the rules of service for judicial officers.

The content of Article 1(1) of the Act on bailiffs indicates that judicial enforcement is a task of the state and defines how this task should be performed. It also lays down the basis for further systemic solutions, redefining the purpose and scope of administrative supervision of bailiffs, the link with judicial supervision,

2 Act of 26 June 1974 - Labour Code, Dz.U. (Journal of Laws) of 1974 no. 24, item 141, as amended.

3 Marciniak, A., Wprowadzenie do działu II, in: Marciniak, A. et al. (eds.), Kodeks postepowania cywilnego. Tom III. Komentarz. Art. 730-1088, Warszawa 2015, pp. 565-567.

4 Act of 22 March 2018 on bailiffs, Dz.U. (Journal of Laws) of 2018, item 771, as amended.

5 Act of 28 February 2018 on bailiff costs, Dz.U. (Journal of Laws) of 2018, item 770. 
the functions and tasks of bailiffs' self-governing bodies, and the training of future bailiffs. The new Act does not cover enforcement fees (bailiff costs), which are dealt with in the separate Act on bailiff costs. ${ }^{6}$

The Act on bailiffs also introduced changes to the Code of Civil Procedure, which are covered by Article 833, among others. Currently, $\$ \$ 1^{1}$ and 2 read as follows:

$\$ 1^{1}$. The provisions of Article 87 and Article $87^{1}$ of the Labour Code apply respectively to unemployment benefits, activation allowances, scholarships, and training allowances paid under the Act of 20 April 2004 on employment promotion and labour market institutions. ${ }^{7}$

$\$ 2$. The provisions of Article 87 and Article $87^{1}$ of the Labour Code shall apply respectively to the salaries of MPs and senators, the dues of members of agricultural production cooperatives and their household members for work in a cooperative, and the salaries of members of labour cooperatives.'

In addition, the following $\$ 2^{1}$ has been added: The provisions of Article 87 and Article $87^{1}$ of the Labour Code shall apply respectively to all recurring benefits whose purpose is to provide a livelihood or which constitute the sole source of income for a debtor who is a natural person'. Likewise, $\$ 3$ has the following wording: 'The restrictions provided for in paragraphs 2 and $2^{1}$ shall not apply to the claims of members of agricultural production cooperatives on account of their share of the cooperative's revenue accruing to them from contributions to the cooperative.'

The provisions of Article $833 \$ \$ 2$ and $2^{1}$ of the Code of Civil Procedure contain a limitation on enforcement related to recurring payments whose purpose is to ensure subsistence, other than remuneration for work. They are subject to enforcement to the extent specified in the provisions of Articles 87 and $87^{1}$ of the Code of Civil Procedure, as respectively applied. ${ }^{8}$

The previous Article $833 \$ 2$ of the Code of Civil Procedure raised doubts as to the interpretation of whether the remuneration received by a debtor employed under a civil-law contract may be considered a recurring payment aimed at ensuring maintenance. There is no doubt that people employed under civil-law contracts, although they constitute a considerable percentage of the workforce, are still in a much worse situation than people employed under employment contracts. Thus,

6 Reiwer, R., Ustawa o komornikach sadowych. Komentarz, in: Reiwer, R. (ed.), Ustawa o komornikach sadowych. Ustawa o kosztach komorniczych. Komentarz, Warszawa 2019, p. 4; Reiwer, R., O potrzebie uchwalenia nowej ustawy o komornikach sadowych, in: Marciniak, A. (ed.), Założenia projektu nowej ustawy, Sopot 2014, pp. 9-11.

7 Act of 20 April 2004 on employment promotion and labour market institutions, Dz.U. (Journal of Laws) of 2017, item 1065.

8 Wiśniewski, A., Komentarz do art. 833 k.p.c, in: Jankowski, J. (ed.), Kodeks postępowania cywilnego. Tom II. Komentarz. Art. 730-1217, Warszawa 2019, pp. 554-556. 
in terms of ensuring their minimum subsistence and protection against enforcement, the legislature introduced $₫ 2^{1}$ in order to equate them unequivocally with individuals with the status of employees within the meaning of the Labour Code. ${ }^{9}$ Despite the good intentions of the legislature, this provision still raises doubts about the phrase 'ensuring livelihood. The editors of 'Rzeczpospolita' asked the Ministry of Justice to elucidate the meaning of the phrase 'ensuring livelihood. Consequently, on 19 December 2018, the Ministry explained that:

'- the term should be understood in the same way as in the legislation in force until the end of 2018, with the proviso that this legislation expressly covers contractors as well;

- as regards the very concept of "assurance of livelihood," it should be pointed out that the position expressed in judicial case law is that this concept should be given a broad meaning and that the inclusion of a given payment in the group of payments in question depends solely on the determination of whether the payment is of a periodic (recurring) nature and fulfils the above-mentioned objective;

- recurring payments are entitlements paid to the debtor periodically at recurring intervals.' ${ }^{10}$

As regards the interpretation of the notion of 'ensuring maintenance', the judgment of the Appellate Court in Łódź - according to which 'there is no doubt that the recurring payments which are intended to ensure maintenance also include remuneration paid under civil-law contracts (such as lease agreements). Legal scholars and commentators emphasize that the concept of recurring payments whose purpose is to provide for maintenance should be given a broad meaning. The inclusion of a given payment in the group of payments depends solely on determining whether the payment is of a periodic (recurring) nature and whether it meets the purpose indicated above. Recurring payments are payments paid periodically to the debtor at recurring intervals. ${ }^{.11}$

It follows from the above that those cash payments which are recurring and which provide a livelihood or are the debtor's only source of income are eligible for deduction.

Therefore, the upper limit on deductions for income from civil-law contracts is as follows:

9 Justification of 24 May 2017 to the government act on bailiffs, http://www.sejm.gov.pl/sejm8.nsf/ druk.xsp?nr=1582 (accessed 22.06.2020).

10 Pigulski, M., Zarobki zleceniobiorców silniej chronione od 2019 r., "Rzeczpospolita" 3.01.2019,, https://www.rp.pl/Kadry/301039989-Zarobki-zleceniobiorcow-silniej-chronione-od-2019-r.html (accessed 28.01.2020).

11 Judgement of the Appellate Court in Łódź of 13 February 2014, I ACa 1057/13, LEX no. 1438078. 
- in the case of execution for maintenance, $3 / 5$ of the salary,

- in the case of execution for other claims or deduction of cash advances, $1 / 2$ of the salary, and

- when the deductions from various titles related to execution under the enforcement order for payment of claims other than maintenance and cash advances are combined, up to $1 / 2$ of the salary, and up to $3 / 5$ of the salary, including the deduction of maintenance claims.

As 'Rzeczpospolita' rightly pointed out, ${ }^{12}$ the amended provisions do not result from the amended legislation:

'- whether, in order to determine the free amount, when the contractor's remuneration is of a recurring nature and constitutes his/her only source of subsistence, the amount of the minimum remuneration for work applicable to employees (PLN 2,250 for full-time employment) or the minimum hourly rate for contractors (PLN 14.70) multiplied by the number of hours spent executing the order in a given month should be adopted;

- how to determine the free amount in the case of a merger with an order'.

In its explanations of 19 December 2018 submitted to the editorial office of 'Rzeczpospolita', the Ministry of Justice took the position that

'- in relation to persons performing work on the basis of a contract of mandate, a free amount must be applied in the amount of the statutory minimum wage currently payable to employees (provided, of course, that in the given circumstances the conditions of Article $833 \$ 2^{1}$ of the Code of Civil Procedure are met);

- on the basis of the legal status in force until the end of 2018, opinions are expressed that by analogy, it should be assumed that in the case of a contractor, the free amounts are reduced as in the case of part-time employment - in accordance with Article $87^{1} \S 2$ of the Labour Code; ${ }^{13}$

- in the case of working for one employer at the same time on the basis of an employment contract and a contract of mandate, the bailiff's determination of the amount exempt from deductions should take into account the total income obtained from both sources (this issue, in the absence of an explicit regulation, will be clarified only by the court's jurisprudence); the department has confirmed by telephone that a similar principle applies to merging jobs and orders from different entities.'

12 Ibidem.

13 The Ministry, however, reserved the opinion that the development of judicial practice in this respect against the background of the amended provisions can only take place in connection with the examination of complaints against the action of a judicial bailiff. 
An employer of contractors should know, if necessary, when the limit of deduction can be applied and the amount exempt from deduction, equal to the minimum wage for a given year. Therefore, it is possible to take this decision if the employer, having obtained from the bailiff the seizure of the contractor's claims, has knowledge that the remuneration transferred to the employee due to the contract of employment

- is of the nature of a payment paid periodically at recurring intervals, and

- its purpose is to provide a livelihood or it constitutes the sole source of income for the debtor, who is a natural person.

Undoubtedly, the application of the new rules limiting the enforcement of recurring payments intended to ensure subsistence, other than remuneration for work, requires appropriate retrospection.

First of all, it should be determined whether the contractor's claim enjoys protection against deduction, as the employing entity deducts from the claim of a debtor who is a natural person on the basis of a notification from a bailiff or administrative enforcement authority. As a rule, the notice does not explicitly mention the application or non-application of the provisions on protection against execution to a given claim. If a given claim meets the conditions for such protection, the debtor should file a request at the enforcement authority, as the enforcement authority considers each case individually. The basis for the application by an employer of contractors, of the limit of deduction and the amount exempt from deductions will be a letter from the enforcement authority in this case. It should then be determined whether the debtor is entitled to protection against deductions. If so, the limit of deduction and the amount exempt from deduction must be determined.

If a limit of deduction and a non-deductible amount should be applied to the debtor's claim according to the letter of the enforcement authority, the determination of these amounts depends on the type of relationship between the parties. The subject to social insurance contributions or taxation of, for example, the contract on which the work is based may vary. While a deduction should be made from the net amount of the remuneration actually due to the debtor, the determination of a non-deductible amount will, as in the case of employees, be independent of the remuneration to be paid.

Moreover, it should be remembered that in the event of an unjustified transfer of the entire remuneration due to the contractor by the principal to the bailiff, the debtor has the right to submit a request to limit the enforcement (Article $833 \$ 2^{1}$ of the Code of Civil Procedure) in order to prove that the conditions justifying the proper application of the provisions of the Labour Code to the payment received by him under the contract of mandate are met. 


\section{Restrictions on judicial enforcement in selected EU countries}

As it has already been described above, people employed under civil-law contracts are in a much worse situation than those employed under employment contracts. In order to protect them from enforcement, the legislature introduced $\$ 2^{1}$ into Article 833, containing a limitation of enforcement relating to recurring payments whose purpose is to ensure subsistence, other than remuneration for work. Similar solutions can also be found under the provisions of the civil procedure codes in force in Germany, France, Sweden, and Spain.

Compulsory enforcement in Germany ${ }^{14}$ is regulated mainly by $\$ 704$ et seq. of the Code of Civil Procedure (Zivilprozessordnung [ZPO]) and by the Act on forced sales and receivership (Gesetzüber die Zwangsversteigerung und Zwangsverwaltung [ZVG]). 'The debtor's movable assets, claims, and other property rights and real property can be subject to enforcement. $\$ 811 \mathrm{ZPO}$ specifies the movable assets that cannot be attached; the aim is to allow the debtor and his/her household to retain the minimum that is essential for personal or professional use. Restrictions on attachment also apply to the debtor's earned income. $\$ 850$ et seq. ZPO provide for certain amounts that cannot be attached, as the debtor needs them to provide for his subsistence. Credit balances can be protected in an "account exempted from attachment" (Pfändungsschutzkonto, $₫ 850 \mathrm{k}$ ZPO). Certain amounts exempt from attachment are held in these accounts irrespective of the origin of the credit balance.' ${ }^{15}$ Thus, it is easy to see a similarity between the German 'minimum of subsistence' and the Polish 'ensuring maintenance'.

Further similarities can be seen in French law, ${ }^{16}$ according to which a creditor can pursue a claim against all the debtor's assets; therefore, 'in principle, all assets belonging to the debtor' can be seized. There are specific rules depending on the type of such assets: claims (rent, remuneration, or funds accrued in a bank account), movable property of all kinds, immovable property and rights in rem, securities and rights attached to shares, vehicles (land vehicles, vessels, boats, or aircraft), copyright rights, sums of money deposited in a safe, etc. 'However, by way of exception, the law states that certain assets may not be attached. This is the case, in particular, for sums needed for maintenance; thus, for example, it is not possible to attach all of a person's earned income because that person has to keep a sum sufficient to meet his or her everyday needs. The amount of that sum is set

14 Official website of the European Union, https://e-justice.europa.eu/content_procedures_for_enforcing_a_judgment-52-de-pl.do?member=1 (accessed 22.06.2020).

15 Ibidem.

16 Official website of the European Union, https://e-justice.europa.eu/content_procedures_for_enforcing_a_judgment-52-fr-pl.do?member=1 (accessed 22.06.2020). 
each year and takes into account the amount of earned income and the number of dependants [sic]. ${ }^{17}$

Swedish law, ${ }^{18}$ like Polish law, uses the term 'amount necessary to maintain.' In order for property to be attached, certain conditions must be met. 'The property must belong to the debtor, be transferable, and have some monetary value. Attachment may be used to claim property of any kind. (...) Earnings, pensions, etc. may also be subject to attachment. Some property cannot be attached. This is the case with beneficial property. The rules on beneficial property generally apply only to natural persons. (...) Attachment of earnings may only apply over and above the amount that the debtor needs to maintain him/herself and his/her family.' ${ }^{\prime 19}$

While the Spanish Code of Civil Procedure ${ }^{20}$ does not introduce terms such as 'minimum of subsistence' or 'ensuring maintenance', it does detail the extent of the restrictions on enforcement of remuneration for work and, moreover, 'salaries, wages, pensions, remuneration, or their equivalent not exceeding the amount of the minimum wage, which, in the author's view, can be considered recurring payments, which are explicitly referred to in the Polish Code of Civil Procedure. Interestingly, the regulations limiting enforcement apply to revenue from professional and commercial activities carried out on the basis of self-employment. With regard to the attachment of wages and pensions, the Code of Civil Procedure lays down, in Article 607, the following preclusions:

1. Salaries, wages, pensions, remuneration or their equivalent not exceeding the amount of the minimum wage (set annually by the government) are exempt from attachment.

2. Salaries, wages, remuneration or pensions above the minimum wage may be attached according to the scale below:

a) for the first additional amount up to the amount equivalent to twice the minimum wage, $30 \%$;

b) for the additional amount up to the amount equivalent to three times the minimum wage, $50 \%$;

c) for the additional amount up to the amount equivalent to four times the minimum wage, $60 \%$;

17 Ibidem.

18 Official website of the European Union, https://e-justice.europa.eu/content_procedures_for_enforcing_a_judgment-52-se-pl.do?member=1(accessed 22.06.2020).

19 Ibidem.

20 Official website of the European Union, https://e-justice.europa.eu/content_procedures_for_enforcing_a_judgment-52-es-pl.do?member=1, (accessed 22.06.2020). 
d) for the additional amount up to the amount equivalent to five times the minimum wage, $75 \%$.

e) For any amount that exceeds the above amount, $90 \%$.

3. If the party against whom enforcement is sought receives more than one salary or wage, all of them will be added together and the unattachable part deducted once only [sic!]. Unless separate estates are in place for the spouses, and proof of this is provided to the Clerk of Court, the spouses' salaries, wages and pensions, emoluments, or equivalent shall be combined.

If the party against whom enforcement is sought has dependants, the Clerk of Court may reduce percentage points laid down in points 1-4 of this Article by between 10 and 15 per cent. 5. If the salaries, wages, pensions, or remuneration were encumbered with permanent or temporary deductions of a public nature pursuant to tax or social security legislation, the net amount received by the judgment debtor after those deductions will be the amount used as the basis for determining the amount to be seized.

4. The previous paragraphs of this Article shall apply to revenue from professional and commercial activities carried out on a self-employed basis.

5. The amounts seized in accordance with this provision may be transferred directly to the party seeking enforcement, into an account previously designated by said party, if approval is granted by the Clerk of Court responsible for enforcing the seizure.21 $^{21}$

In the author's opinion, the examples presented above demonstrate a certain similarity among the European Union member states in terms of regulations concerning enforcement from remuneration for work, and in particular leaving debtors with the means necessary to support themselves and their families.

\section{Conclusion}

Execution from remuneration for work is one of the most common ways of enforcing a judgement. The correct application of the regulations governing it provides the creditor with an opportunity to obtain his or her claim, often in a relatively short time. The biggest problem can be simply discovering where the debtor is employed. The measure of the disclosure of assets (Article 913 et seq. of the Code of Civil Procedure), as well as the procedure introduced into the Code of Civil Procedure of ordering a bailiff to search for the debtor's assets for remuneration

21 Ibidem. 
(Article 7971 of the Code of Civil Procedure) may be helpful in determining the place of a debtor's employment.

Furthermore, it should also be stated that not all of the payments included in the enforcement from remuneration for work will be subject to enforcement on the basis of the provisions relating to remuneration for work. It must also be underlined that the literal interpretation of Article $833 \$ 1$ of the Code of Civil Procedure discusses the remuneration referred to in the Labour Code. In the phrase 'remuneration from the employment relationship', this provision narrows down the payments referred to in the remuneration for work that is enforceable, under Article $881 \S 2$ sentence 2 of the Code of Civil Procedure, to the remuneration for work in the strict sense of the Labour Code. Andrzej Marciniak presented a similar position in the literature on enforcement proceedings. ${ }^{22}$ The jurisprudence of the Supreme Court also speaks in favour of adopting such a stance. First of all, it should be emphasised that the Supreme Court has protected under Article 87 of the Labour Code payments other than remuneration, by analogy, taking into account the similarity of the function and nature of these payments to remuneration (payments resulting from the employment relationship, being monetary in nature, and providing funds for the maintenance of the employee, calculated on the basis of remuneration for work, the size of the payments depending on the length of service). It can therefore be argued that the case-law has developed criteria which allow the payment to be characterised as remuneration, whereas payments which do not meet those criteria are not characterised as remuneration.

Until the end of 2018, a bailiff had been unable to seize the entire remuneration of a person working on the basis of an employment contract, whereas in the case of contractors and persons performing work, it was possible. The increase in the number of civil-law forms of employment meant that debtors increasingly often lacked the means to live. The newly added Article $833 \$ 2^{1}$ of the Code of Civil Procedure was meant to change the prevailing situation. However, likely contrary to the legislature's intentions, the new regulations will not protect contractors or employees. Bailiffs still have the possibility to seize one's entire payment, and they will release part of it only when the debtor shows that part of the seized funds is necessary for his or her life.

22 Marciniak, A., Komentarz do art. 881, in: Marciniak, A. et al. (eds.), Kodeks postępowania cywilnego. Tom III. Komentarz. Art. 730-1088, Warszawa 2015, pp. 570-572. 


\section{References}

Marciniak, A., Komentarz do art. 881, in: Marciniak, A. et al. (eds.), Kodeks postępowania cywilnego. Tom III. Komentarz. Art. 730-1088, Warszawa 2015.

Marciniak, A., Wprowadzenie do działu II, in: Marciniak, A. et al. (eds.), Kodeks postępowania cywilnego. Tom III. Komentarz. Art. 730-1088, Warszawa 2015.

Pigulski, M., Zarobki zleceniobiorców silniej chronione od 2019 r., "Rzeczpospolita" 3.01.2019, https://www.rp.pl/Kadry/301039989-Zarobki-zleceniobiorcow-silniej-chronione-od-2019-r.html.

Reiwer, R., O potrzebie uchwalenia nowej ustawy o komornikach sadowych, in: Marciniak, A. (ed.), Założenia projektu nowej ustawy o komornikach sąowych, Sopot 2014.

Reiwer, R., Ustawa o komornikach sądowych. Komentarz, in: Reiwer, R. (ed.), Ustawa o komornikach sadowych. Ustawa o kosztach komorniczych. Komentarz, Warszawa 2019.

Seweryński, M., Wynagrodzenie za pracę. Pojęcie, regulacja i ustalanie, Warszawa 1981.

Szubert, W., Zarys prawa pracy, Warszawa 1976.

Wiśniewski, A., Komentarz do art. 833 k.p.c., in: Jankowski, J. (ed.), Kodeks postępowania cywilnego. Tom II. Komentarz. Art. 730-1217, Warszawa 2019.

CITATION

KUCHTA, D., The influence of the act of 22 March 2018 on bailiffs on amendments to the Code of Civil Procedure regarding execution from remuneration for work, "Acta Iuris Stetinensis" 2020, No. 1 (Vol. 29), 73-85, DOI: 10.18276/ais.2020.29-06. 